\title{
Unified classification of defects detected by the technical examination
}

\author{
Victoriya Klimina $^{1}$, Alexey Yurgaitis ${ }^{1,{ }^{*}}$, and Dmitriy Topchiy ${ }^{1}$ \\ ${ }^{1}$ Moscow State University of Civil Engineering, 26, Yaroslavskoye Shosse, Moscow, 129337, Russia
}

\begin{abstract}
The article is devoted to the problem of the absence of the unified defects classification within the multipurpose technical test of buildings and constructions on the territory of the Russian Federation. It draws attention to the significance of detected faults finding and their risks in the case of the further building usage. The extract from the authorial Defects Classification created for inspection of bearing structures of largepanel, monolithic and brick buildings is given in the article to demonstrate the ways of examining the above mentioned constructions.
\end{abstract}

\section{Introduction}

Nowadays, a relevant area of research, optimization and improvement includes common procedures for multipurpose technical inspection of buildings and structures, potentially produced at all stages of construction projects [1-10]. Thus, if the new construction specifies the correctness of the construction and installation works, it brings the revelation of all sorts of defects and deviations in the operated building that may affect the safety of the technical operation of the building. At the same time, in the case of defects, specialists in technical inspection of buildings can't always unambiguously characterize their impact on the technical condition of the building as a whole only on the basis of empirical knowledge. In this situation, according to the authors, there is a need for a harmonized and unified system of classification of damages and defects, which allows largely on the one hand to systematize most of the most common defects in the types of structural material, on the other hand - to give a numerical expression of the potential impact of this destructive factor on the complex technical condition of the building, which would formalize and optimize the process of establishing the category of technical condition of structures and buildings as a whole.

\section{Materials and Methods}

Inspection of buildings and structures implies a complex procedure aimed at determining the technical parameters of the object and establishing the need for repair, reconstruction or strengthening of structures. Since in the future all undetected defects (physical, technical or any other shortcomings of the building) can lead to an emergency condition, which in turn

* Corresponding author: aljurgaitis@gmail.com, vika.klimina@yandex.ru 
will affect the safety of life and health of people, it is necessary that qualified specialist with strict observance of the methodologies inspects the building

Regulations such as:

- GOST 31937-2011 "Buildings and structures. Rules of inspection and monitoring of technical condition";

- GOST R 53778-2010 "Buildings and structures. Rules of inspection and monitoring of technical condition";

- SP 13-102-2003 "Rules of inspection of bearing structures of buildings and structures";

- VSN 53-86 (p) "Rules for assessing the physical deterioration of residential buildings";

- "Classifier of the main types of defects in the construction and construction materials industry", etc.

At the same time, in accordance with the decree of the government of the Russian Federation of December 26, 2014 №1521, only GOST 31937-2011 is mandatory, while the rest are only recommendations, and, consequently, the instructions and requirements prescribed in them can be ignored.

According to GOST 31937-2011 "Buildings and structures. Rules of inspection and monitoring of technical condition" , a detailed inspection of structures should be passed only if the visual inspection of the object under examination revealed damage and deficiencies affecting the stability, strength and stiffness parameters of the building. At the same time, a detailed analysis of the object, in particular its structural form, takes a lot of time and is expensive.

But how to be sure that the detected damage will not affect the strength characteristics of the building (construction)? Now there is no approved strict systematization of defects in the regulatory framework of the Russian Federation and in each case the conclusion about the condition of the building is made on the basis of many years of experience, and thus directly depends on the human factor. A young specialist may not have enough knowledge to predict how the identified damage will develop in the future and affect the technical characteristics of the building. At the same time, the classification developed on the basis of the experience of dozens of engineers, supported by the mathematical justification of the data obtained, could give an accurate assessment of the state of the structure, taking into account not only the personal safety of people, but also their comfort.

Before offering the classification of defects, we will consider already existing in the territory of the Russian Federation presented in "the Qualifier of the main types of defects in construction and the industry of construction materials" approved by the Main Inspectorate of Gosarkhstroynadzor of Russia on November 17, 1993. According to this document, all shortcomings of buildings listed in it are divided into only 2 groups - critical and significant.

However, in the presence of this division, the parameters that affect the hit of the defect in a particular category are nowhere spelled out. In addition, this classifier can be used only immediately after the completion of construction and installation works, because it does not take into account possible damage received directly during the exploitation of a building or structure, such as chipped protective layer of concrete, rusting of metal structures or rotting of wood.

During the research, foreign experience on this problem was also studied. For example, in the UK the Building research establishment (BRE) engaged in the development of national and international standards and the building regulations, in 1995, proposed his own classification of damage to brick and masonry. Based on 3 criteria, such as "aesthetics", "serviceability" and "stability", they divided all defects into 6 possible categories from 0 to 5 (table 1). In addition, scientists from BRE found that according to statistics, the appearance of defects often contribute to deviations from the required standards in standard construction, rather than innovative technologies or unique in its execution objects. 
Table 1. Classification of visible damage to the walls of brick and stone masonry.

\begin{tabular}{|c|c|c|}
\hline Category & Description of the fault & Necessary steps to repair the damage \\
\hline 0 & Cracks less than $0.1 \mathrm{~mm}$ are classified as minor. & No action is required. \\
\hline 1 & $\begin{array}{c}\text { Fine cracks up to } 1 \mathrm{~mm} \text {. Damage limited to the } \\
\text { inner walls, not observed in the external } \\
\text { masonry. }\end{array}$ & $\begin{array}{c}\text { Easily hidden by surface repair and } \\
\text { finishing works. }\end{array}$ \\
\hline 2 & $\begin{array}{l}\text { Cracks up to } 5 \mathrm{~mm} \text { wide which are easy to fill. } \\
\text { Cracks are not necessarily visible from the } \\
\text { outside, but require additional action to ensure } \\
\text { protection from atmospheric influences. }\end{array}$ & $\begin{array}{c}\text { Periodic cracks can be masked by means of } \\
\text { appropriate overlays. If necessary, } \\
\text { adjustment of doors and windows is } \\
\text { required. }\end{array}$ \\
\hline 3 & $\begin{array}{c}\text { Cracks from } 5 \text { to } 15 \mathrm{~mm} \text {, or several cracks, the } \\
\text { size of the order of } 3 \mathrm{~mm} \text {. They are open and } \\
\text { require the work of a bricklayer. Doors and } \\
\text { Windows can be displaced, pipes can be } \\
\text { damaged. }\end{array}$ & $\begin{array}{l}\text { It is necessary to replace a part of a laying. } \\
\text { Restore the tightness of the walls. Adjust } \\
\text { doors, windows, replace pipes. }\end{array}$ \\
\hline 4 & $\begin{array}{c}\text { Cracks from } 15 \text { to } 25 \mathrm{~mm} \text {, or several cracks of } \\
\text { smaller width. Windows and door frames are } \\
\text { badly damaged. The walls are noticeably convex, } \\
\text { the floor is inclined. There is damage in the } \\
\text { bearing beams. }\end{array}$ & $\begin{array}{c}\text { Destruction and replacement of sections of } \\
\text { walls, especially over doors and windows } \\
\text { are required. }\end{array}$ \\
\hline 5 & $\begin{array}{l}\text { Cracks greater than } 25 \mathrm{~mm} \text {, or several cracks of } \\
\text { smaller width. The bearing beams are badly } \\
\text { damaged. The walls are noticeably tilted and } \\
\text { require support. The windows are slanted. } \\
\text { Danger of walls collapsing. }\end{array}$ & $\begin{array}{l}\text { In an unambiguous order capital repairs } \\
\text { with partial or full reorganization of the } \\
\text { building are necessary. }\end{array}$ \\
\hline
\end{tabular}

Thus, the Construction research institution not only divides the damage into categories of their importance, but also specifies the minimum requirements for their elimination and further normal operation of the building and structure.

\section{Results and Discussions}

This problem is also considered in his work "Building Pathology. Principles and Practice" David S. Watt, who proposes to re-categorize all the shortcomings depending on the priority of repair and construction works into 3 groups: "urgent", "necessary" and "desirable". Depending on the occurrence of the defect in a particular group, the requirements for planning and scope of repair activities will be dictated. David S. Watt proposes to give an assessment of the severity of the damage and assign the appropriate priority to eliminate it after consideration:

- obligations prescribed by law;

- health and safety documents;

- functional and operational requirements

- data on the rate of deterioration and destruction;

- values and utility of the building (construction);

- desired and expected results;

- operating costs.

The procedure for classifying defects is a very complex and discrete task, since the probability of occurrence of defects depends on a large number of factors [11-13]. The 
reason may be as climatic effects, violation of technology in construction and installation works, non-compliance with temperature and humidity conditions indoors, and not according to the purpose of the building and its actual operation. Unfortunately, it is impossible to predict all possible options. Therefore, in order to be able to push off some data, the authors have compiled a classification of the most common damage to vertical and horizontal load-bearing structures for monolithic, brick and large-panel buildings on the basis of defective sheets of several representative objects located in the city of Moscow (table 2-4).

Table 2. Classification of defects of load-bearing structures of large-panel buildings.

\begin{tabular}{|c|c|c|}
\hline Name of the structure & Description of the defect & Assessment of repeatability \\
\hline Internal wall panels & $\begin{array}{l}\text { Cracks opening width of } 0.1-0.2 \mathrm{~mm} \text { on } \\
\text { the protective layer of concrete wall } \\
\text { panels, extending from the boundaries or } \\
\text { corners of the through openings. }\end{array}$ & $16 \%$ \\
\hline the same & $\begin{array}{c}\text { Vertical crack widths of } 0.1-0.2 \mathrm{~mm} \\
\text { protective layer of concrete load-bearing } \\
\text { wall panels. }\end{array}$ & $11 \%$ \\
\hline the same & $\begin{array}{l}\text { Vertical and horizontal cracks opening } \\
\text { width of } 0.1-0.2 \mathrm{~mm} \text { on the protective } \\
\text { layer of concrete bearing wall panels. }\end{array}$ & $5 \%$ \\
\hline the same & $\begin{array}{l}\text { Damage to the protective layer of } \\
\text { concrete panels repaired with cement } \\
\text { mortar. Crack network in the repair } \\
\text { composition is marked. }\end{array}$ & $10 \%$ \\
\hline the same & $\begin{array}{l}\text { Wetting of finishing layers and concrete } \\
\text { bearing wall panels of the corridor, } \\
\text { which arose due to the prevailing } \\
\text { temperature and humidity conditions of } \\
\text { the room. }\end{array}$ & $3 \%$ \\
\hline the same & $\begin{array}{l}\text { Cleavage of the protective layer of } \\
\text { concrete panels with denudation and } \\
\text { corrosion of reinforcement. }\end{array}$ & $2 \%$ \\
\hline the same & $\begin{array}{l}\text { Nodes mates wall panels with the panels } \\
\text { of the ceilings were not plastered, or } \\
\text { plastered with the exposure of } \\
\text { substandard steel embedded parts and } \\
\text { connecting elements. }\end{array}$ & $3 \%$ \\
\hline Slabs & $\begin{array}{l}\text { Longitudinal cracks opening width } 0,1- \\
0,2 \mathrm{~mm} \text { on the protective layer of } \\
\text { concrete slabs. }\end{array}$ & $6 \%$ \\
\hline the same & $\begin{array}{l}\text { Chips of a protective layer of concrete } \\
\text { and damage of armature of a plate of } \\
\text { overlapping in a place of the admission } \\
\text { of engineering communications. }\end{array}$ & $6 \%$ \\
\hline the same & $\begin{array}{l}\text { Lack of resting the slabs on the wall } \\
\text { panel. }\end{array}$ & $5 \%$ \\
\hline
\end{tabular}




\begin{tabular}{|c|c|c|}
\hline Name of the structure & Description of the defect & Assessment of repeatability \\
\hline the same & $\begin{array}{c}\text { Hairline cracks at the bottom faces of the } \\
\text { slabs, resulting from the wetting of } \\
\text { modular designs in the manufacture, } \\
\text { storage and installation. }\end{array}$ & $13 \%$ \\
\hline the same & $\begin{array}{c}\text { Traces of soaking of plates of } \\
\text { overlappings, which have arisen at } \\
\text { warehousing, storage and installation of } \\
\text { designs. }\end{array}$ & $10 \%$ \\
\hline the same & $\begin{array}{c}\text { Chip protective layer of concrete slab. } \\
\text { the same }\end{array}$ & $\begin{array}{c}\text { Slabs on the walls of the stairwell are } \\
\text { installed with an offset relative to each } \\
\text { other due to poor installation. }\end{array}$ \\
\hline
\end{tabular}

Table 3. Classification of defects of bearing structures of monolithic buildings.

\begin{tabular}{|c|c|c|}
\hline Name of the structure & Description of the defect & Assessment of repeatability \\
\hline Pylons & $\begin{array}{l}\text { Damage to the protective layer of } \\
\text { concrete to a depth of } 30 \mathrm{~mm} \text {, } \\
\text { which occurred during the laying } \\
\text { of engineering networks. }\end{array}$ & $3 \%$ \\
\hline Internal walls & $\begin{array}{l}\text { Non-design hole } Ø 100-250 \mathrm{~mm} \text {, } \\
\text { made with damage to the } \\
\text { reinforcement of monolithic } \\
\text { reinforced concrete wall. }\end{array}$ & $10 \%$ \\
\hline the same & $\begin{array}{l}\text { Mounting of the monolithic } \\
\text { doorway in the wall. }\end{array}$ & $16 \%$ \\
\hline the same & $\begin{array}{c}\text { Crack opening width of } 0.1 \mathrm{~mm} \\
\text { on the protective layer of concrete } \\
\text { wall from the corner of the } \\
\text { doorway. }\end{array}$ & $13 \%$ \\
\hline the same & $\begin{array}{l}\text { Vertical crack opening width of } \\
0.1 \mathrm{~mm} \text { on the protective layer of } \\
\text { concrete wall. }\end{array}$ & $4 \%$ \\
\hline the same & $\begin{array}{l}\text { Design opening Increased by } \\
\text { height } \mathrm{h}=200-250 \mathrm{~mm} \text {, is } \\
\text { executed with damage of } \\
\text { reinforcement of a monolithic } \\
\text { reinforced concrete wall. of } \\
\text { reinforcement. }\end{array}$ & $10 \%$ \\
\hline the same & $\begin{array}{l}\text { Sinks and voids on the protective } \\
\text { layer of concrete wall. }\end{array}$ & $7 \%$ \\
\hline Slabs & $\begin{array}{l}\text { Cleavage of the protective layer } \\
\text { of concrete to a depth of } 30 \mathrm{~mm} \\
\text { with exposure of the bars of the } \\
\text { lower reinforcement plate in place } \\
\text { of holes } \varnothing 20-50 \mathrm{~mm} \text {. }\end{array}$ & $7 \%$ \\
\hline
\end{tabular}




\begin{tabular}{|c|c|c|}
\hline Name of the structure & Description of the defect & Assessment of repeatability \\
\hline the same & $\begin{array}{l}\text { Extension of the design of the } \\
\text { hole or the new hole size up to } \\
800 \mathrm{~mm} \text { in two directions in the } \\
\text { slab with denudation of the } \\
\text { reinforcement rods. }\end{array}$ & $4 \%$ \\
\hline the same & $\begin{array}{l}\text { Expansion of the design hole or a } \\
\text { new hole up to } 800 \mathrm{~mm} \text { in two } \\
\text { directions in the slab with the } \\
\text { reinforcement bars cut. }\end{array}$ & $6 \%$ \\
\hline the same & $\begin{array}{l}\text { Non-design holes } \varnothing 100 \mathrm{~mm} \text { made } \\
\text { "in place" with damage to the } \\
\text { reinforcement plate. }\end{array}$ & $12 \%$ \\
\hline the same & $\begin{array}{l}\text { Oblique crack opening width of } \\
0.2-0.5 \mathrm{~mm} \text { on the protective } \\
\text { layer of concrete slab. }\end{array}$ & $4 \%$ \\
\hline the same & $\begin{array}{l}\text { Crack opening width of } 0.2-0.5 \\
\text { mm on the protective layer of } \\
\text { concrete from the angle of the } \\
\text { project opening. }\end{array}$ & $4 \%$ \\
\hline
\end{tabular}

Table 4. Classification of defects of load-bearing structures of brick buildings.

\begin{tabular}{|c|c|c|}
\hline Name of the structure & Description of the defect & Assessment of repeatability \\
\hline Internal walls & $\begin{array}{l}\text { Damage to the masonry walls } \\
\text { according to the slope of the } \\
\text { doorway incurred in the } \\
\text { dismantling and finishing } \\
\text { plaster layers. }\end{array}$ & $4 \%$ \\
\hline the same & $\begin{array}{l}\text { Insufficient length of the } \\
\text { platform of support of the } \\
\text { crosspiece of the doorway on } \\
\text { a wall laying. }\end{array}$ & $7 \%$ \\
\hline the same & $\begin{array}{l}\text { Low-quality device of a } \\
\text { bricklaying of an internal wall } \\
\text { or its site. }\end{array}$ & $19 \%$ \\
\hline Exterior walls & $\begin{array}{l}\text { Damage to the brickwork of } \\
\text { the bearing wall in the } \\
\text { supporting area of the floor } \\
\text { beams. }\end{array}$ & $11 \%$ \\
\hline the same & $\begin{array}{l}\text { Damage of a bricklaying of a } \\
\text { wall on a slope and in a basic } \\
\text { zone of a crosspiece of a } \\
\text { window aperture. }\end{array}$ & $11 \%$ \\
\hline the same & $\begin{array}{l}\text { The lintel of the window } \\
\text { opening is missing }\end{array}$ & $26 \%$ \\
\hline the same & $\begin{array}{l}\text { There are no bearing masonry } \\
\text { brick walls at the lintel. }\end{array}$ & $22 \%$ \\
\hline
\end{tabular}




\section{Conclusions}

In further studies of the data in terms of various structural elements and defects, the results will be refined and supplemented. It ultimately will lead to the creation of a regulatory document, which will provide a unified classification of all possible defects detected in the complex technical inspection of buildings and structures for systematization and algorithmization the process of obtaining an opinion on the technical condition (integral category of technical condition) of the building at the current moment.

\section{References}

1. D. Topchiy, A. Shatrova, A. Yurgaytis, MATEC Web of Conferences, 193, 05032 (2018) doi.org/10.1051/matecconf/201819305032

2. D. Topchiy, E. Kochurina, MATEC Web of Conferences, 193, 05012 (2018) doi.org/10.1051/matecconf/201819305012

3. D. Topchiy, A. Tokarskiy, MATEC Web of Conferences, 196, 04029 (2018) doi.org/10.1051/matecconf/201819604029

4. D. Topchiy, A. Shatrova, International Journal of Mechanical Engineering and Technology, 9, 539-547 (2018)

5. D. Topchiy, A. Tokarskiy, IOP Conference Series: Materials Science and Engineering, 365, 062005 (2018)

6. I. Abramov, A. Lapidus, E3S Web of Conferences, 33, 03066 (2018) doi.org/10.1051/e3sconf/20183303066

7. I. Abramov, E3S Web of Conferences, 33, 03075 (2018) doi.org/10.1051/e3sconf/20183303075

8. A. Lapidus, I. Abramov, MATEC Web of Conferences, 193, 05033 (2018) doi.org/10.1051/matecconf/201819305033

9. V. A. Pukhkal, A. B. Mottaeva, Magazine of Civil Engineering, 81(5), 202-211 (2018) doi: 10.18720/MCE.81.20

10. A. Baiburin, Procedia Engineering, 206, 807-813 (2017) doi.org/10.1016/j.proeng.2017.10.555

11. O. Ivankovaa, L. Konecnaa, Procedia Engineering, 190, 199-206 (2017) doi.org/10.1016/j.proeng.2017.05.327

12. N. Ahzahar, N. Karim, S. Hassan, J. Eman, Procedia Engineering, 20, 249-255 (2011) doi.org/10.1016/j.proeng.2011.11.162

13. J. Adam, J. Moreno, M. Bonilla, T. Pellicer, Engineering Failure Analysis, 70, 212-221 (2016) doi.org/10.1016/j.engfailanal.2016.09.004 